should in general be limited to 4 or 5 c.c.; injection should immediately cease if pain in groin or rectum occurs, since such pain shows irritation of ras or vesicle, sometimes requiring mitigation by morphin. If the vas be occluded by stricture, severe pain may be caused by the injection of even 1 or 2 c.c. Regurgitation of collargol into the connective tissue around the opening in the vas follows overdistention; and causes a tender induration which gradually subsides, usually without suppuration.

If there be no occlusion of the seminal duct, collargol is passed with the urine for days following the injection, and the emitted semen is black-the latter phenomenon inspired in one pationt the fear that his future chililren might be Ethiopians. When the weaker, nonirritating solutions are used at body temperature, the distended vas and vesicle may expel their contents into the urethra and bladder or even out of the meatus, so that a stream of black liquid flows from the syringe of the operator through the entire genital luct, escaping at the meatus. In these cases the opening of the ejaculatory duct into the prostatic urethra can usually be identified through a modern urethroscope, and a filiform bougie be passed into the duct.

By fastening into the vas a flanged silver tube the injection or irrigation may be repeated subsequently at the discretion of the operator.

Among the features revealed by this method are: (1) a peristalsis of ampulla and vesicle into the prostatic urethra, without the phenomena of emission-a function which explains certain obscure clinical phenomena; $(2)$ the sphincteric closure of ampulla and vesicle; (3) the not infrequent ocelusion of the ejaculatory duct, converting vas and vesicle into a retention cyst. Elaboration of these and other features cxceeds the limits of this preliminary article, which is lesigned to bring this new means of studying the genital duct to the attention of the profession.

32 North State Strcet.

\section{TWO UNCOMMON ESOPHAGEAL CASES}

\section{ANTHONY IBASSLER, M.D.}

Protessor of Cilnleal Medicine, New York I'olyclinic Medical School and IIospltal: Visiting l'hysielan, New York Polyellnie IIospitul: Chlef Gastro-Lnterologlst, German Polikinlk; Visiting Gustro-Enterologist, Peoples Hospltal NEW YORK

'The first case is of interest in slowing the length of time that a large and irregular-shaped foreign body ean be retained in the esop'ragus, the conclusions arrived at as to the safest procedure for its removal, and the operation.

CAsE 1.-J. S. (referred by D). Harry Jandesman, Now York), aged 34, married, machine worker in factory, whose family and persomal history were negative, had been perfectly well up to nine weeks before I saw him, when, during his sleep one night, he was awakened by a strangling sensation and a pain in his throat. Within a moment he noticed that the right incisor tooth of the upper jaw, with the plate on which it was attuched, was missing. He made efforts with his fingers to extract the plate from his thront but could not feel it. After an hour or two the symptoms of distress sub. sided and he fell asleep ugain. When he awoke in the morning his throat was sore, swollen and "reddish looking," and he had indefinite painful sensations in the upper part of his neck in the lateral hyoid regions. For two day's he could not sivnllow anything. About the third day he began to get down come fluid, and each day thereafter he swallowed with less distress until, at the time I saw him (eight weeks after), he was partaking of fluid and semisolid foods. The patient had no puin under ordinary conditions, but when he made effort at swallowing he had a sticking sensation in the lateral hyoid regions high in the front of nis neck, but no distress in the stermal refion. This distress he described as the presence of somethner interfering with his swallowing. Dr. Landesman reported that he had passed a bougie several times into tho patient's stomach, and had not noticed any obstruction, and the patient stated that he had examined his stools for tho first four weeks and had not recovered the plate.

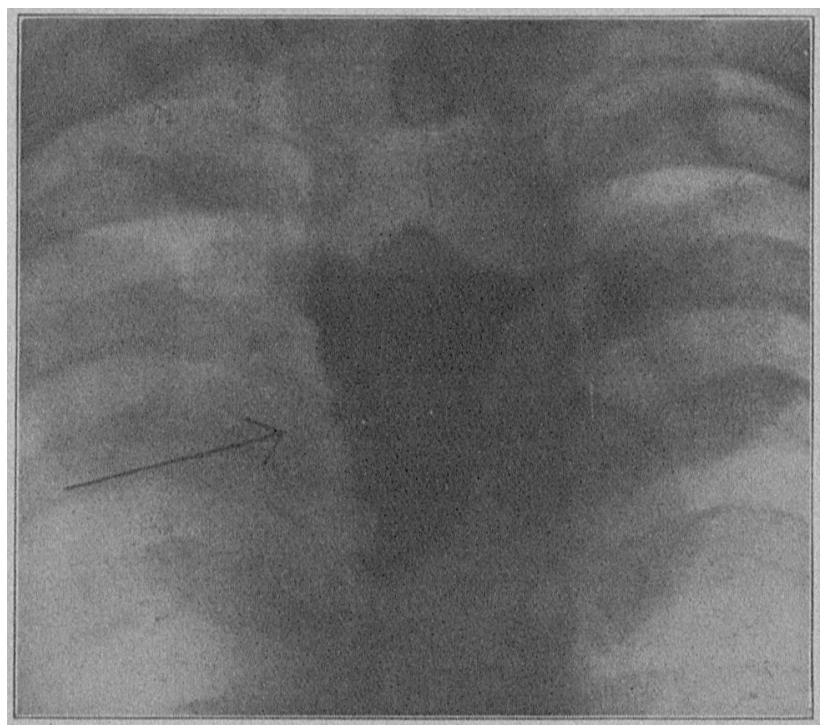

Fig. 1.-Antropostepinr skfagram showlng the plate lodged at the level of the third and fourth dorsal vertebrae, and the clavicles In front (Case 1 ).

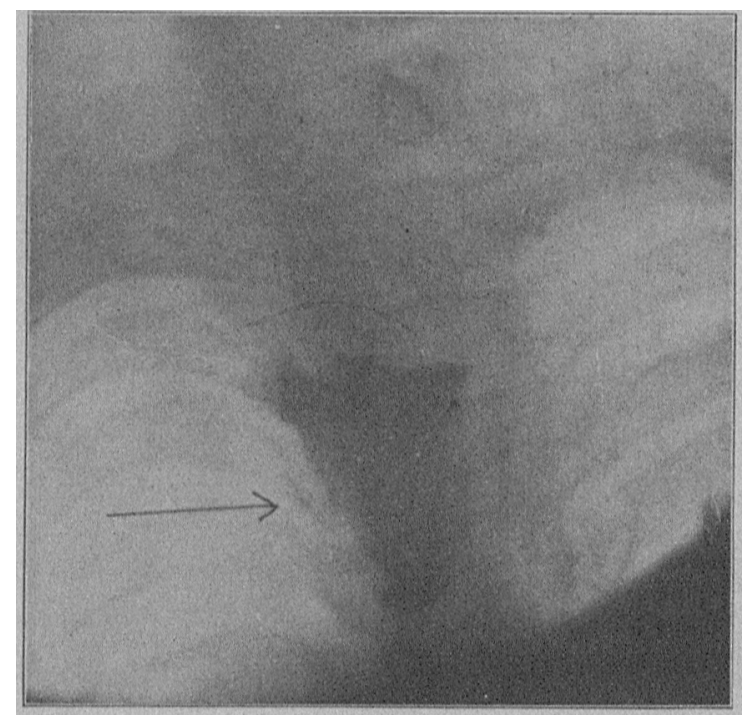

Fig. 2--Slightly luteral position showing the plate lodged at the sume level as shown in Flgule 1 (Case 1).

Examination was negative, except that the patient had a slight degree of pharyngitis. The tip of a stomach-tube was arrested about the upper part of the sternal region. I did not pass a bongie, feeling that if the plate was lodged there it might cause a jupture of the esophagus. 'The patient described the tooth-plate as having one tooth fastened to it; it had a lower entting edge and an upper edge which was flattened and sharp. He said that the plate was made of rubber, and originally had a clamp at both ends to hold it io certain teeth, but that one of these clamps lad been broken off for some time. (The lower end of the plate as seen in 
Fignre I shows this perforet and to be pointed downward.) lla salid that the phate Wits a narrow ome. Was pointed at both emls, und hat a sharp pesterior edlate. The two skiagrams (ligss. 1 and 2) show the shatiow to he ansiderably wider than the description of the plata he gave and more irregular in outline thum only such a plate would throw. My axsumption was that he probably had some ulecration in the esophagas aromel it accouting for this.

While it would he all easy matter to pass an esophangoseope and sejze the phate with an esophangus clamp, it is evident that the plate would have to be seized at the point where the odge was noted through the esurgagoseope, there being little or no choice in the selection. The entire assemblage, that is, the esophagosespe and the clamp with the plate fustened at its lower end, would then be delivered by simple direet tratetion. Since the laryngopharyogal junction is marrow, and a third skingram showed that the tooth-phate was in the position which when drawn upward hat the two shurp elges of the tooth on one side and the knife elge of the bick of the plate on the other, it was plain that the opening of the esophagus

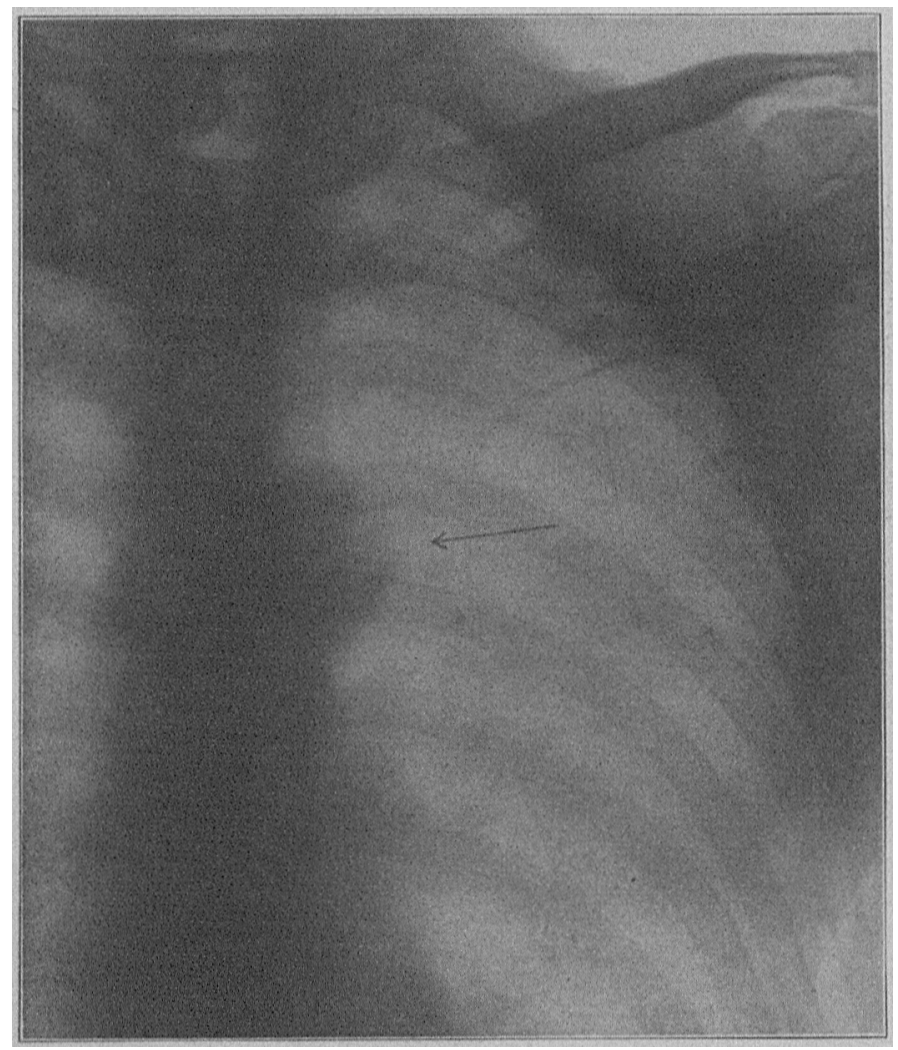

Vigr 3 -Anteroposterlor skingram showing alciliention of the arel of the aorta, and other culcareous masses in tha lungs (Cuse 2 ).

would probably be badly cut in delivering the plate, thereby encouraging the danger of a collulitis of the throut with $n$ prossible edema of the glottis. Since the main dunger of its removal was a subsequent collulitis, 1 decided that this would le minimized to the greatest extent by not endenvoring to rentove the plate by the esophateresepe but by an open operation at the side of the neck. 'J his was done one week afterwarl. Two days before it was performed, the patient began to complatin of pains in lis right and left thorax, mainly in the right shoulder ynning down the arm, which pains prev'ented bim from sleeping.

Description of the operation ly Dr. J. P. Grant at Dr. J. A. Wyeth's elinie, ut the New York Polvelinie Hospital: "The patient was placed on the table with shoulders slightly olevated and face turned to the right. On the left side an incision was made, beginning at the level of the thyroid cartilage and extending downward along the anterior imargin of the left sternomastoid for alout three inches. The akin, platysma, and superficial and deop fascine were divided. It
Was a iso fouthl neessary in order to have a good exposure to divide the omolyoid. The thyroid fland and the trachea were then retrueterl to the right. The carotid shouth was next identified and retracted to the left. An esophlagenl bougie was then passed. At a point as deep in the neck as possible, the esophaticus wats soized with volsollum foreeps and a longitudinal s)it made over the hougie. The bougre was then withdrawn and the finger inserted into the esophagenl wound. The plate was located apparently opposite the second costosternal junction, its base directed upward with the angle on the left side firmly imbedled in the exoplungus. This projecting angle was lroken of and removed with a pair of foreeps, after which the plate was readily extracted. The wound was then lightly packed with gatre and pationt rotumed to bed. Jor nine days the patient was nourished ly rectum and kept sitting up in bed. and dressings were clunged daily. On the tenth day the patient was given liquids bo mouth and. there being no escape through the esophagenl wound, nourishment continued to be given this way. Ilis convalescence was uneventful in every way."

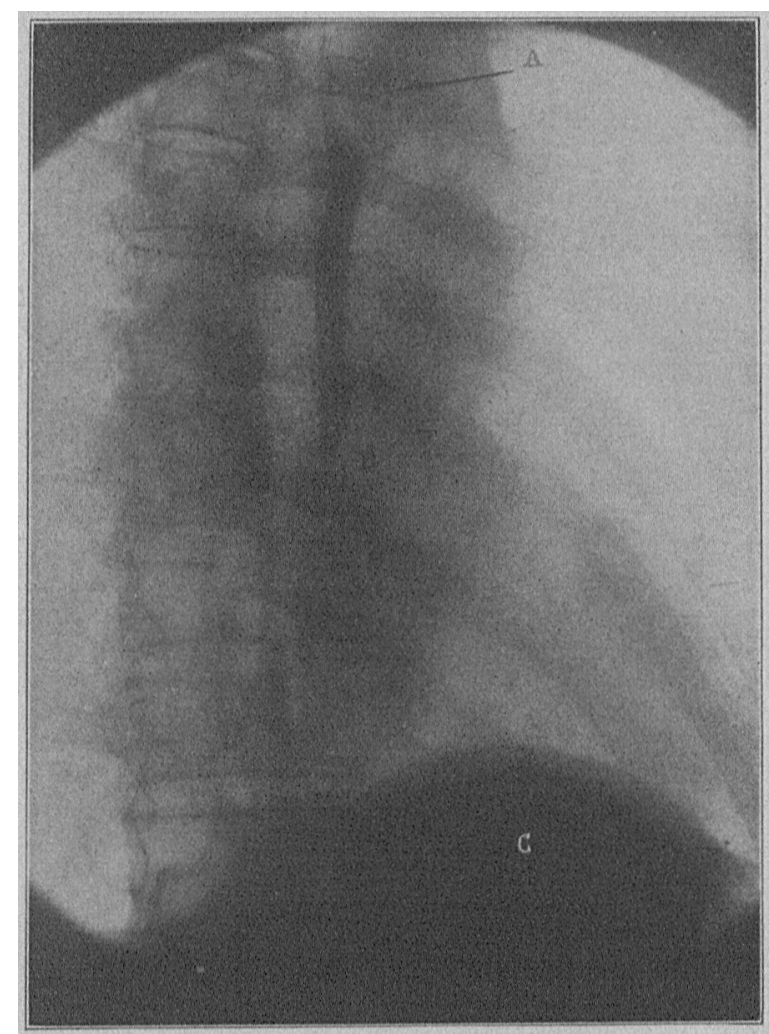

Fig. 4.- Dorsolnteral skingram showing pressure on the esophagus by the arch of the norta $4 \mathrm{t} A$, pressure on the esophagus by the base of the henrt at $B$, and a retention in the esophagus between the two points, und bismuth in the stomach at $C$ (Case 2$)$.

The second case is of interest in slowing a type of esoplangeal obstruetion which has not been recognized as yet and which accounted for a peculiar swallowiag sympton.

Cuss 2.-Mr. C. H. S. (referred by Dr. Stephen Lee, Eust Orange, N. J.), aged 78 , married, nanufacturer, family his. tory negative, at the age of 30 notied a swelling in the root of his neck on the right side. This was diagnosed by Dr. Willard Purker and Dr. Sunds as an aneurysm of the sub. clavian artery for which nothing was done, and the growth lats not enlargel in the last forty-eight years. The patient look exceptionally good care of himself in the way of diet, exercise, sleep, etc.

About tive years ago lie noticed a stinging and distressing semsation in the right chest wher: he swallowed acid food or drink. 'l his was particularly' noticenble when he drank lemon. 
nde or ate stewed tomatoes. Tlis stinging sensation, when prominent, gave him llasless of distress down the left arm. He stated that he had no distress excepting when he partook of acjd things, and then only for from five to ten minutes after he had swallowed, that partaking of these ncid things did not canse him distress in the stomach, and that smelı distress us he had was entirely substernal.

Examination revialed a lall, thin type of man with all aneurysm of the second portion of the subelavian artery on the right side of the si\%e of a small peach. No radial pulse was pulpable on the right side. 13lood-pressure, systolic, 186; diastolic, 100. Jistinct atheroma of the right brachial. Urine comtuined increased amounts of ilidican, no albumin or easts. The heart was enlarged, and the aortic somml ncentuated. There was general atomy of the hollow viscern of the abdomen, and the second swallowing sound delayed to 30 seconds.

While the dianoses of senility, nnewrym of the right subalavian artery, chronic excessive intestimal putrefaction of the inclolic type. and arteriosclerosis, with gastro-enteric atony were possible, the main point in this comection was the interesting symptoms pertaining to swallowing. 'lise supposition linst was that the patient probably had an aneurysm in the arels of the aorta, although no physical signs suggested this. The dingnosis of the canse of the swablowing symptom was made and confirmed by $a-1$ aly (ligrs. 3 and 4 ).

It is therefore plain that this inan land a calcification of the asorta: the pressure on the gullet at that area cuused by this calcification, and a pressure exerted on the asoplagus by the "1рия purt of the buse of the leart, together cunsod a slight delay in transit in this portion of the tube. When the food or lrink was of an acid nature, it irrituted the mucons membrane of the esophagus at this midportion, and the patient had the symptoms described, which snbsided in a fow minutes when the contents in the esoplangus had beun deliveled into the stomach.

\section{THE PREVENTION OF ARTERIOSCLEROSIS ANI) HEAR'T JISEASE $1 \mathrm{~N}$ O'THERTISE HE.LL'IHY INIIVIIUATS PAS'I MIIODLE LIFE* \\ LOLIS WALGWRES BISHOP, A.M., M.D.

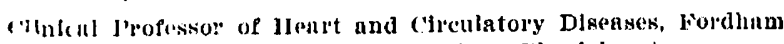 Intrersity school of Medicine; Pliysictan to the lancoln llospital \\ NEW YOHK}

Fvery observing person whose experience extends past to knows that heart disense is coustantly developing among his contemporaries who are otherwise healthy. Surprise is often expressed that this man or that, in spite of what seemed to be right living, has becone a victim of heart clisease.

'I'he slightest consideration leads to the belief that there is some active or hidden agent working to cause heart disease and hardening of the arteries, and a little axamination shows that the causes are not those usually assigned. The healthy old drunkard disproves alcohol as a cause. Rheumatism more often attacks the young, and in later life generally spares the heart and bloodvessels. Men who really overwork are not so mumerous as is often thought, and wory, while a great canse of heart disease, is indirect in its effect.

'The fact is constantly appearing in the literature of the day that circulatory disease, as shown by statistic's, is more frequent than formerly. 'Tuberculosis has for its victims the most attractive of the youth of the land, but heart disease (laims the best and most suecessful of those past micldle life. Much attention is being directed to tuberculosis because its cause and progress have

* Iterd before the Fiftenth International congloss on liygiene and Demography, Wrshlngton, $D$. C.. Sept. 27, 1912 . become matters of public lnowledge. The victims of heart disease, however, still too often go lor months and years without intelligent treatment because no one has pointed out the danger-signals and because the interest in grerm disease has absorbed every one's attention.

Heart disease and hardening of the arteries in nine times out of ten are, 1 believe, due to disturbances of the chemistry of the borly. 'The prevention of heart disease and hardening of the arteries must be accomplished by a proper regulation of the chemistry of the body, particularly that pertaining to the intestines and the liver. 'This is accomplished thromgh diet, rest and exercise, througl, the administration of certain well-defined rencedies, and the limitation of nervous strain, than which nothing is more potent to npset the bolily rhemistry. The teclmical chemistry involved is difficult and complicated in the extreme, and entirely beyond the comprehension of those not specially trained in the chemistry of this particular branch of work.

The truth is not found in popular explanations with such trite names as "jntestinal fermentation," but in the ultimate chemistry of food substances and their changes in the human bolly.

The tendency to heart iliscase in otherwise healthy individuals past miclle life can better be detected liy a chemical examination of the mine than by an examination of the henrt itself. By the time the heart itself: shows poisoning, as appleciated by the sufferer because of palpitation, pain or shortness of breath, irretrievable damage luas been done, and the ehemical vice has become so deeply seated that an extreme regimen is necessary, while in the early stages a slight modification of diet and hygiene can check the tromble.

It is often remarked that the consumptive is fortunate who early in his disease has a severe hemorrhage that thoroughly comvinces him of the necessity of treatment. In the beginning, heart disease and hardening of the arteries unfortumately have no symptoms, and the rhanges in the organs themselves are such as can be detected only by the most expert examination. Fortunate is the subject of these changes if the disturbing chemistry of the body leads to pronounced suffering in the direction of recurrent headache, bilionsness or dyspepsia before the heart and blood-vessels are damaged, because these things may lead to treatment and prevention.

'l'he prevention of heart disease and arteriosclerosis in otherwise healthy persons past middle life can be accomplished infallibly only when there is a periodic chemical examination of the todily chemistry at stated intervals by an expert chemist, and when early and proper courses of treatment counteract the tendency before damage is done.

Some of the large life-insurance companies are now examining for this underlying chemical cause of heart disease in otherwise healthy persons who apply for large policies, and yet one of the saddest examples that I ever witnessed of chemical clamage to the heart and bloodressels was the case of the medical officer of one of these very companies.

My conclusions are the result of a practice devoted exclusively to the practical cal'e of heart patients, but I would urge on my colleagnes who are privileged to do laboratory research work its vitally important bearing on the life and well-being of mankind at the most useful period of life. 'The prevention of arteriosclerosis nnd heart disease in otherwise healthy persons past middle life thus brings up a problem that is seldom considered. However much constant observation may tend to the 